\title{
ISOLATION AND SELECTION OF ALKALINE PROTEOLYTIC BACTERIA FROM LEATHER PROCESSING WASTE AND ENZYME CHARACTERIZATION
}

\author{
BUDIASIH WAHYUNTARI', NISA R MUBARIK- and MARITA ANGGARANi ${ }^{2}$ \\ Agency for the Assessment \& Application of Technology, Jakarta, Indonesia \\ ${ }^{2}$ Bogor Agricultural University, Bogor, Indonesia
}

\begin{abstract}
The aims of this experiment were to isolate alkaline protease producing bacteria from leather processing waste, and to study the biochemical properties of the enzyme produced by the selected bacteria.

Nine bacterial isolates incubated at $37 " \mathrm{C}$, revealed proteolytic activity on skim milk containing media. Four isolates were grown at $\mathrm{pH} 9$ and another four isolates at $\mathrm{pH} 10$ and only one isolate at $\mathrm{pH} 11$. However, in further subculture, there were only three isolates that showed proteolytic activity, namely, D2, D7, and Dll. Among the three isolates, isolate D2 was the highest protease producer. The highest protease production (36.5U/L) was reached after a 36-hr fermentation at $\mathrm{pH} 9$.

The optimum activity of D2 protease was observed at $\mathrm{pH} 8$ and 60"C. The enzyme was stable at pH range of 7-10, and at temperature of 52-62"C. In the presence of 5mM EDTA or PMSF, the crude enzyme activity decreased to $7.04 \%$ and $23.29 \%$ respectively, which indicated that the enzyme might be a metal dependent serine protease. Zymogram analysis revealed the molecular weight of the enzyme was about $42.8 \mathrm{kD}$.
\end{abstract}

Keywords: leather/waste/protease/alkaline

\section{INTRODUCTION}

Alkaline protease, along with other alkaline enzymes such as amylase and cellulose, has been used on an industrial scale. Microbial akaline protease is the enzyme that dominate commercial application, mainly for laundry detergents. Alkaline protease with elastolytic and keratolytic activity is used in the tannery industry for dehairing and the bating of skin and hides (Taylor et al. 1987). Alkaline protease from Bacillus spp. was reported to be used to decompose gelatin on X-ray film for silver recovery (Horikoshi 1996).

Other uses of alkaline protease are for medical purposes, food and chemical industries, as well as in waste treatment plants.

Alkaline protease has been used in industrial scales and has been an attractive option for researchers for the last three decades since the first publication concerning the enzyme by Horikoshi (1971). Studies on exploration of alkaline protease producing microorganisms, which produce novel enzymes have been extensively carried out by researchers all over the world (Banerjee et al. 1999; Singh et al. 2001; Johnvesly \& Naik, 2001; Kanekar et al. 2002, Joo et al 2002; Gessesse et al. 2002; Moreira et al. 2003). 
Most of the alkaline protease producing microorganisms were isolated from natural, as well as manmade alkaline environments. Such microorganisms were also isolated from non-alkaline habitats, such as neutral, and acidic soil (Kumar et al. 1999).

This experiment aims to isolate alkaline protease producing microorganisms from alkaline waste of leather processing and to study the biochemical properties of the enzyme of the selected isolate.

\section{MATERIALS AND METHODS}

\section{Isolation, screening and identification of microbial strains}

The samples for screening were taken from the waste of different leather processing steps including soaking ( $\mathrm{pH} 10)$, liming $(\mathrm{pH} 13)$, and deliming ( $\mathrm{pH}$ 8.5-9.0) from PT. Muhara Dwi Tunggal Laju, and PT. Gunung Putri, in Bogor. The microorganisms were enriched on agar plates containing (gram per liter) 2 gr yeast extract, 0.4 gr $\left(\mathrm{NH}_{4}\right)_{2} \mathrm{SO}_{4}, 1$ gr $\mathrm{MgSO}_{4} .7 \mathrm{H}_{2} \mathrm{O}, 0.5 \mathrm{gr} \mathrm{CaCl} \wedge .2$ $\mathrm{H}_{2} \mathrm{O}, 0.8$ gr $\mathrm{KH}_{2} \mathrm{PO}_{4}, 40$ gr agar, and 8 gr skimmed milk. The $\mathrm{pH}$ medium was adjusted to 8-11 using $\mathrm{NaOH}$. The microorganisms were incubated at $24-40^{\circ} \mathrm{C}$ for 3 days. The colonies which revealed proteolytic activity were then isolated and screened further, using the same composition of medium. The isolates were screened based on proteolytic index which defined as a ratio of clear zone and colony diameter. The isolates that had the highest proteolytic index were screened further for protease production in Luria broth containing $1 \%$ peptone, 0.5 gr yeast extract and $0.5 \% \mathrm{NaCl}$ at $\mathrm{pH}$ 9, 10 and 11. In the same medium composition, they were then incubated in a shaking incubator for 19 hours at $37^{\circ} \mathrm{C}$. The fermented broth was then centrifuged at $4000 \mathrm{rpm}$ for 20 minutes. The protease activity was finally assayed and the isolates were selected based on the protease production.

\section{Protease assay}

Protease activity was measured using a method suggested by Walter (1984). The method was based on amino acid hydrolyzed by the enzyme and was calculated as tyrosine. One unit of enzyme activity was defined as the amount of enzyme which liberate one micromol tyrosine per minute at certain condition.

\section{Preparation of protease}

The selected isolate was cultured in $5 \mathrm{~L}$ fermentor containing $2.5 \mathrm{~L}$ enzyme media production with the same composition as mentioned above with addition of $0.2 \%$ skim milk as an inducer. After a 36 -hr incubation at $37^{\circ} \mathrm{C}$, the fermented broth was filtered using microfilter, and then concentrated further using $10 \mathrm{kD}$ membrane ultrafilter module (Minitan, Milipore). 


\section{Effect of $\mathrm{pH}$ and temperature studies}

The effect of $\mathrm{pH}$ on protease activity produced by the selected isolates was determined at $37^{\circ} \mathrm{C}$ in $50 \mathrm{mM}$ Tris-HCl buffer at $\mathrm{pH}$ 7-8 and in Glycine- $\mathrm{NaOH}$ at $\mathrm{pH}$ 9-11.

To determine the effect of temperature on protease activity, the assay was performed in 50 $\mathrm{mM}$ Tris-HCl buffer $(\mathrm{pH} 8)$ at temperature range of $30-70^{\circ} \mathrm{C}$.

\section{Effect of protease inhibitors and metal ions}

The concentrated enzyme solution was incubated in 2 and 5mM EDTA or PMSF in $50 \mathrm{mM}$ Tris- $\mathrm{HCl}$ at $\mathrm{pH} 8$ for 30 minutes at $5^{\circ} \mathrm{C}$. The same concentration of 2 and $5 \mathrm{mM} \mathrm{MgCl}, \mathrm{CaCl}_{2}$, $\mathrm{ZnCl}_{2}, \mathrm{MnCl}_{2}, \mathrm{FeCl}_{3}$ and $\mathrm{FeSO}_{4}$ were also incubated with the enzyme at $5^{\circ} \mathrm{C}$ for 30 minutes. Residual activity was measured under optimum $\mathrm{pH}$ and temperature. Protease activity assayed in the absence of inhibitors and metal ions was considered as $100 \%$.

\section{Polyacrylamide gel electrophoresis and zymogram analysis}

Zymogram method was employed to determine the molecular weight of the protease. The concentrated enzyme solution was loaded into PAGE containing skimmed milk (0.2\%) which copolymerized with 7.5\% acrylamide. Electrophoresis was run at $110 \mathrm{~V}, 90 \mathrm{~mA}$ for 1.5 hours. After completing electrophoresis, the gel was soaked in $50 \mathrm{mM}$ Tris- $\mathrm{HCl}$ containing $5 \mathrm{mM} \mathrm{CaCl}_{2}$ then incubated at optimum $\mathrm{pH}$ and temperature of the enzyme. Visualization of the enzyme staining activity was carried out by staining the gel in Commassie Brilliant Blue solution. Clear band on the skim milk containing electrophoresis gel indicated the protein band which had shown proteolytic activity. The standard molecular weight marker used was HMW protein standard marker (Amersham).

\section{RESULTS AND DISCUSSION}

\section{Isolation of protease-producing bacteria}

There were 9 isolates which showed proteolytic activity based on clear zone formation on skim milk containing media. Four isolates grew well on media at $\mathrm{pH} 9 \mathrm{~m}$, another four isolates at $\mathrm{pH} 10$, and only one isolate at $\mathrm{pH} 11$. Table 1 shows the physical properties, proteolytic index, and protease activity of the isolates. Proteolytic activity of isolate T4 decreased in the following experiment, and therefore the isolate was excluded. Isolate D2, D7 and Dll were selected based on their proteolytic index and ability to produce protease in submerged culture.

Biochemical characteristics of the selected isolates are displayed in Table 2. Based on their physical, and biochemical characteristics, it can be concluded that the isolates (D2, D7 and Dll) most likely belong to Bacillus spp. 
Table 1. Properties of protease producing isolates

\begin{tabular}{|c|c|c|c|c|c|c|}
\hline Isolate & $\begin{array}{l}\text { Color } \\
\text { (Colony) }\end{array}$ & Gram & $\begin{array}{l}\text { Shape } \\
\text { (Colony) }\end{array}$ & $\begin{array}{l}\text { Shape } \\
\text { (Cell) }\end{array}$ & $\begin{array}{l}\text { Proteolytic } \\
\text { index }\end{array}$ & $\begin{array}{l}\text { Activity } \\
\text { (U/I) }\end{array}$ \\
\hline \multicolumn{7}{|c|}{$\mathrm{pH} 9$} \\
\hline M7 & orange & + & round & rod & 5.33 & 2.6 \\
\hline M8 & white & + & round & rod & 3.87 & - \\
\hline M9 & yellow & + & round & rod & 2.95 & 2.3 \\
\hline M12 & yellow & - & round & rod & 3.83 & 3.3 \\
\hline \multicolumn{7}{|c|}{$\mathrm{pH} 10$} \\
\hline D2 & orange & + & round & rod & 3.67 & 3.7 \\
\hline D7 & white & + & round & rod & 12 & 2.8 \\
\hline D10 & yellow & - & round & coccus & 3.67 & 1.5 \\
\hline D11 & yellow & + & round & rod & 11.08 & 2.7 \\
\hline \multicolumn{7}{|c|}{$\mathrm{pH} 11$} \\
\hline $\mathrm{T} 4$ & yellow & - & round & coccus & 3.69 & 0.0035 \\
\hline
\end{tabular}

Table 2. Biochemical properties of protease producing isolates

\begin{tabular}{|c|c|c|c|c|c|c|c|c|}
\hline \multirow{2}{*}{ Isolate } & \multicolumn{8}{|c|}{ Biochemical test. } \\
\hline & Catalase & Nitrit & Urea & MR & VP & Starch & Indol & $\begin{array}{l}\text { Carbohydrate } \\
\text { fermentation }\end{array}$ \\
\hline \multicolumn{9}{|c|}{$\mathrm{pH} 9$} \\
\hline M7 & + & + & - & - & - & + & - & Acid producer \\
\hline M8 & nd & - & - & - & nd & nd & - & Not detected \\
\hline M9 & nd & + & - & nd & nd & nd & - & Acid producer \\
\hline M12 & + & + & + & - & - & - & - & - \\
\hline \multicolumn{9}{|c|}{$\mathrm{pH} 10$} \\
\hline D2 & + & - & + & - & - & - & - & - \\
\hline D7 & + & $\div$ & - & + & + & - & - & Acid producer \\
\hline D10 & + & + & + & - & - & - & - & Alkaline \\
\hline D11 & + & - & - & - & + & + & - & Acid producer \\
\hline \multicolumn{9}{|c|}{$\mathrm{pH} 11$} \\
\hline $\mathrm{T} 4$ & + & + & + & & - & - & - & - \\
\hline
\end{tabular}

\section{Selection of bacterial strain.}

Further selection of the best proteolytic bacteria was based on the productivity of the isolate at die highest $\mathrm{pH}$. All the isolates screened were grown at three different levels of $\mathrm{pH}(9 ; 10$ and 11). However, all isolates did not grow well at $\mathrm{pH}$ 
11. Figures 1, 2 and 3 reveal growth and protease production rates of D2, D7, and D1l, respectively. The growth rate of isolate $\mathrm{D} 2$ was only slightly better at $\mathrm{pH} 9$ as compared to $\mathrm{pH} 10$. However, its protease production rate at $\mathrm{pH} 9$ was higher than that at $\mathrm{pH} 10$. The highest protease production of isolate D2 was at 36-hour fermentation with a protease concentration of $3.65 \mathrm{U} / \mathrm{l}$.

The growth rate of isolate $\mathrm{D} 7$ at $\mathrm{pH} 9$ was slightly better than at $\mathrm{pH} 10$. However, the protease production rate was higher at $\mathrm{pH} 10$ after 36 hours incubation with the activity of $10.6 \mathrm{U} / \mathrm{l}$.

Figure 3 shows that the growth rate and protease production of isolate $\mathrm{Dl} 1$ was better at $\mathrm{pH} 9$ and with the highest protease production at 24 hour incubation time with enzyme activity of $5.8 \mathrm{U} / \mathrm{l}$. The protease produced by all isolates in skim milk containing medium was much higher as compared to enzyme produced in Luria broth used in early selection of isolates. The data indicated that the enzyme produced by all isolates observed were inducible ones. Among the three isolates observed, isolate D2 produced the highest protease, which showed that the isolate was the most tolerable to alkaline condition. It was assumed that the enzyme belonged to alkaline protease family. Therefore, the enzyme of the isolate was selected for further study.

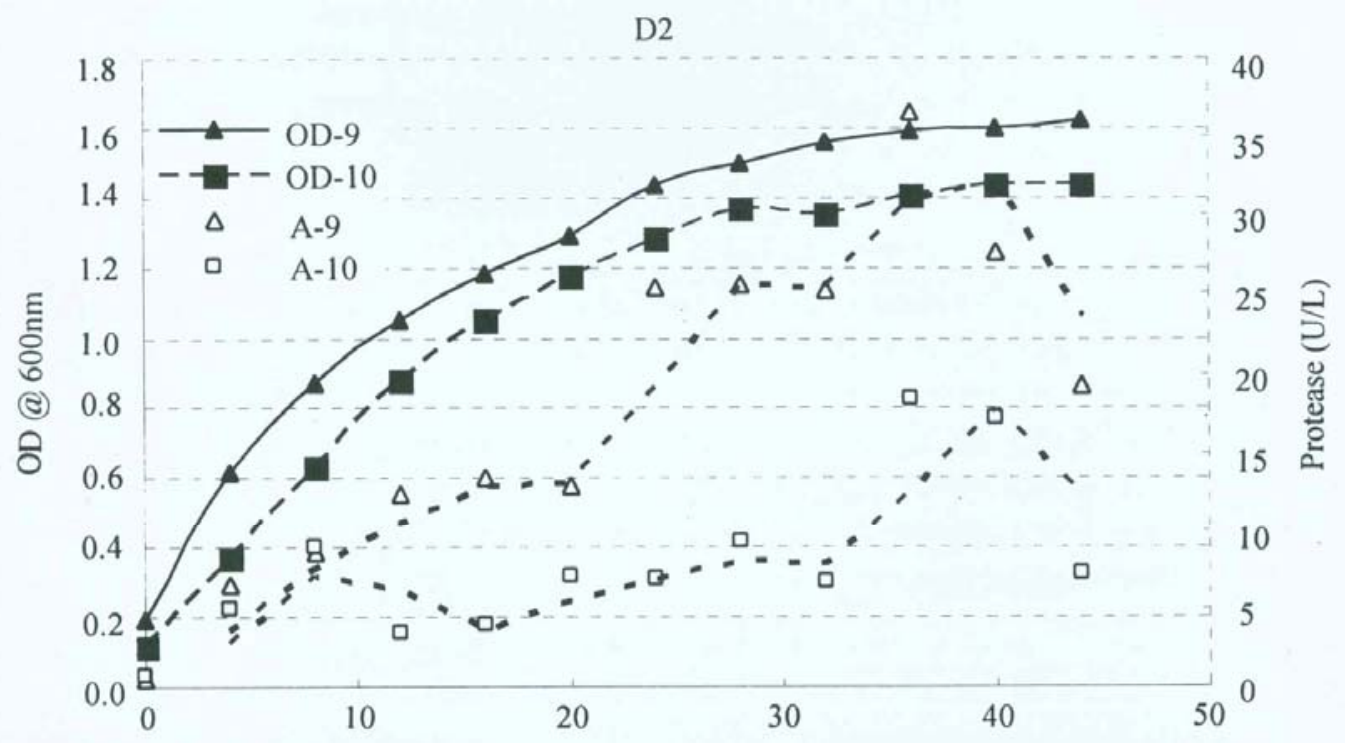

Fermentation time (hr)

$\mathbf{\Delta}$ : growth rate at $\mathrm{pH} 9, \mathbf{a}$ : growth rate at $\mathrm{pH} 10, \triangle$ : protease production rate at $\mathrm{pH} 9, \square$ : protease production rate at $\mathrm{pH} 10$

Figure 1. Growth rate and protease production rate of D2 isolate. 
D7

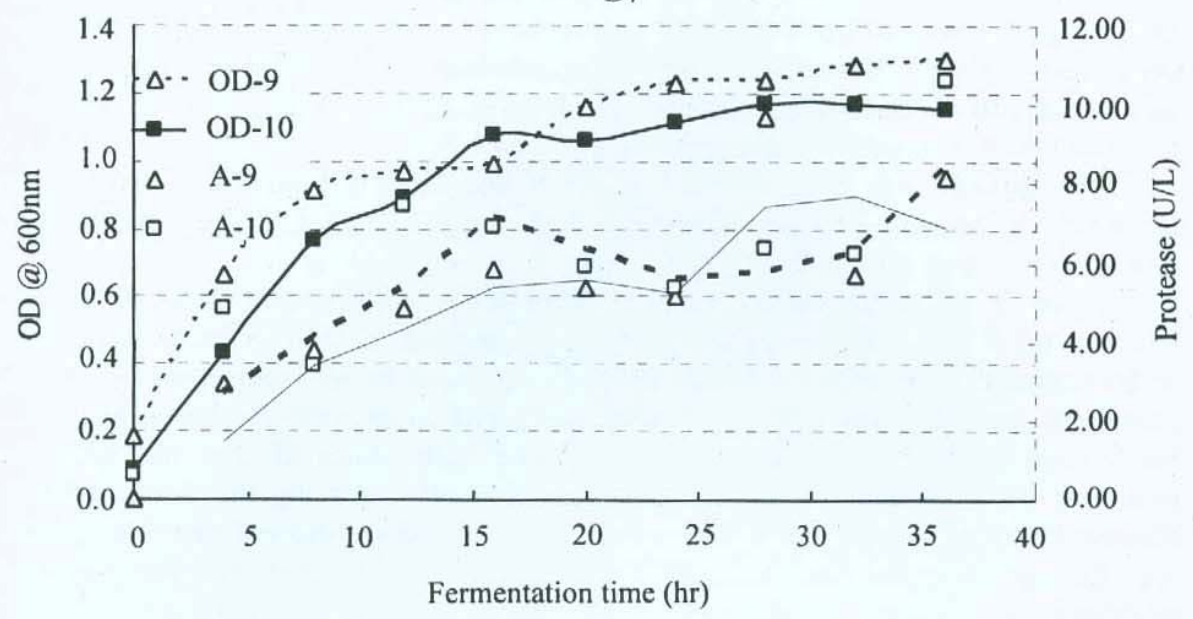

$\Delta$ : growth rate at $\mathrm{pH} 9, \mathbf{0}$ : growth rate at $\mathrm{pH} \mathrm{10, \triangle}$ : protease production rate at $\mathrm{pH} 9, \square$ : protease production rate at $\mathrm{pH} 10$

Figure 2. Growth rate and protease production rate of D7 isolate.

D11

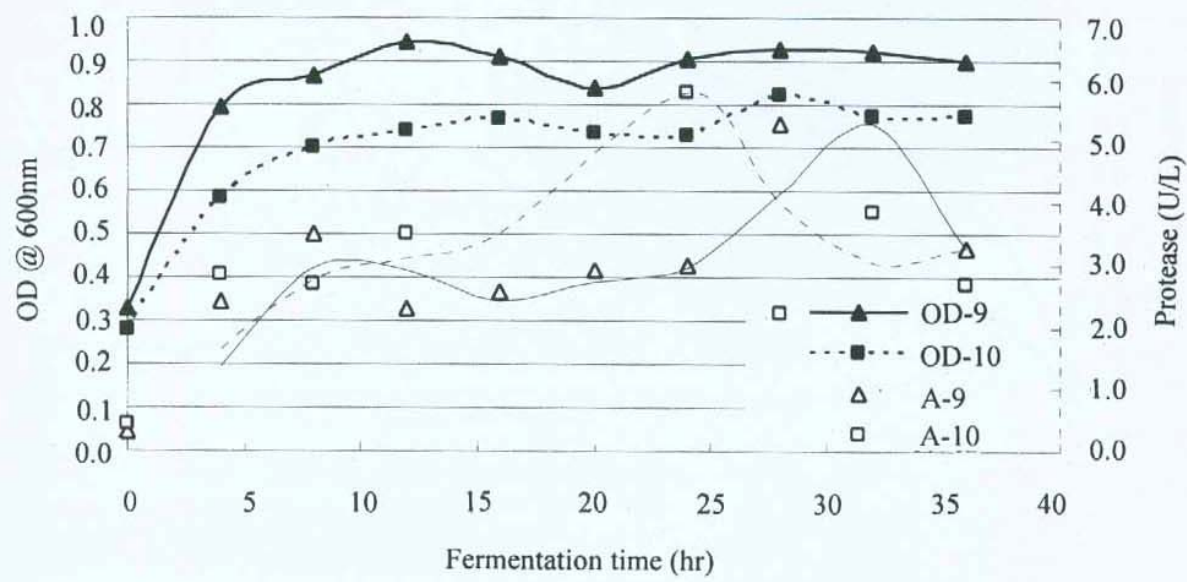

$\Delta$ : growth rate at $\mathrm{pH} 9, \mathbf{0}$ : growth rate at $\mathrm{pH} 10, \triangle$ : protease production rate at $\mathrm{pH} 9, \square$ : protease production rate at $\mathrm{pH} 10$

Figure 3. Growth rate and protease production rate of D11 isolate. 


\section{Effect of pH and temperature study on protease activity}

Optimum activity of D2 isolate protease was observed at $\mathrm{pH} 8$ and $60^{\mathrm{U}} \mathrm{C}$ (Figure 4). The enzyme relative activity was $70 \%$ at $\mathrm{pH} 7$ and 9.5 and at 52 and $62^{\circ} \mathrm{C}$. These data show that the enzyme is an alkalo and thermotolerant one.

Studies on isolation and characterization of alkaline protease have been ongoing for the last three decades (Horikoshi 1996 and Kumar and Takagi, 1998). These are the most recent studies on the subject. Singh et al. (2001) reported that optimum activity of Bacillus sp. SSR1 was reached at the range of $\mathrm{pH} 8-11,40^{\circ} \mathrm{C}$, the optimum activity was shifted up to $45^{\circ} \mathrm{C}$ due to the presence of calcium ions.

Thermostable alkaline protease from Bacillus sp. JB-99 reported by Johnvesly and Naik (2001) had an optimum activity at $\mathrm{pH} 11$ and $70^{\circ} \mathrm{C}$. This bacterium was isolated from sugarcane molasses at $\mathrm{pH}$ 5.8. But with a chemically defined medium, the bacterium was able to produce alkaline thermostable protease.

Gessesse et al. (2002) succeeded in isolating two bacterial strains from Lake Abjata (an alkaline soda lake in Ethiopia), using chicken feather meal as the sole source of nitrogen and carbon. The bacteria were identified as Nestemkonia sp. AL-20 and B. pseudofirmus AL-89. The optimum enzyme activities of AL-20 and AL-89 were observed at $\mathrm{pH} 10,70^{\circ} \mathrm{C}$ and at $\mathrm{pH} 11,50^{\circ} \mathrm{C}$, respectively. The AL-20 protease was calcium independent whereas the AL-89 was calcium dependent. Both enzymes were indicated as serine protease.

Bacillus, horikoshii protease had optimum activity at $\mathrm{pH} 9,45$ "C, and the enzyme was stable at the $\mathrm{pH}$ range of 5.5-12 and temperature up to $50^{\circ} \mathrm{C}$ (Joo et al, 2002).

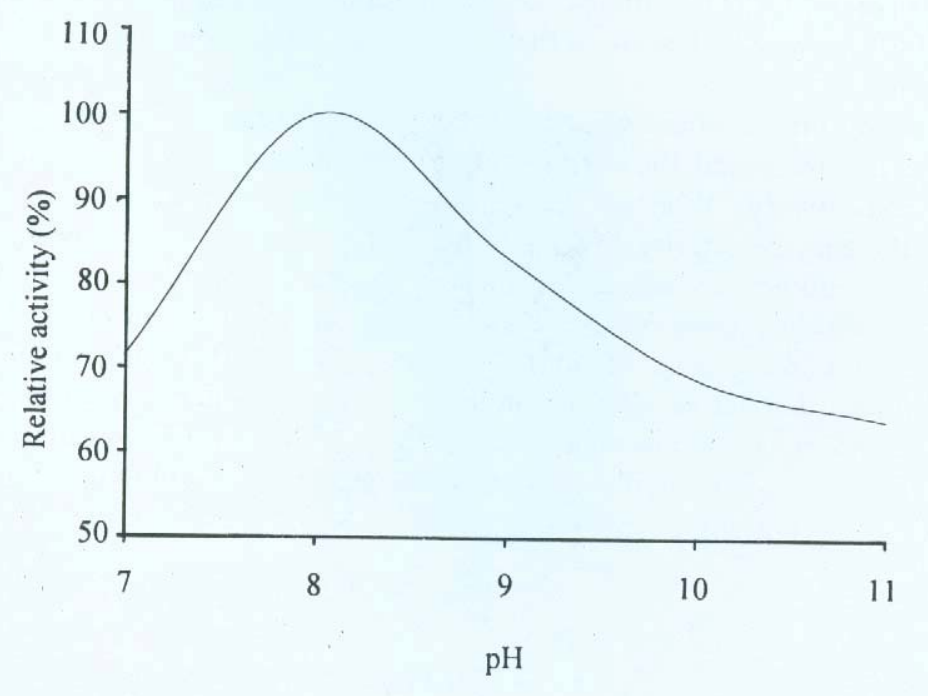

Figure 4. Effect of $\mathrm{pH}$ on protease activity of isolate D2 


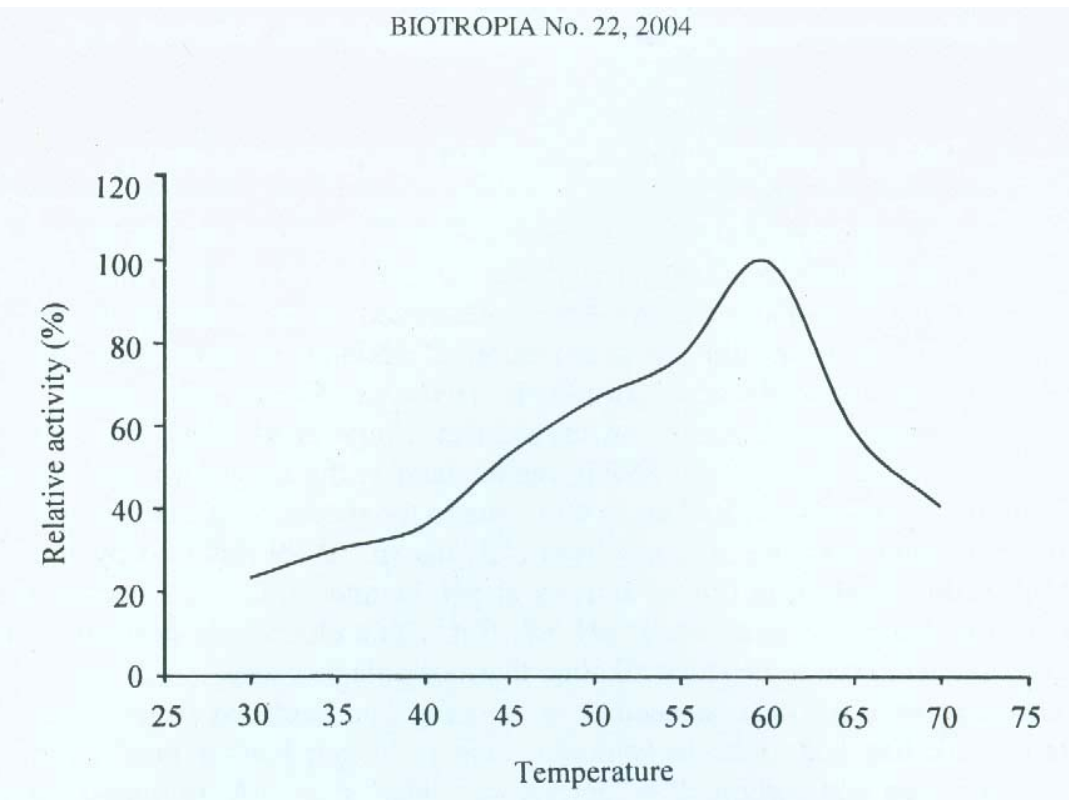

Figure 5. Effect of temperature on protease activity of isolate D2

\section{Effect of protease inhibitor and divalent ions}

The presence of $5 \mathrm{mM}$ phenyl methyl sulfonyl fluoride (PMSF) reduced the protease activity down to $23.3 \%$ which indicated the enzyme belongs to serine protease. Five mM EOT A almost totally inhibiting the enzyme with a remaining activity of $7 \%$ only, which showed that the enzyme activity depends on the presence of metal ion.

The study on the effect of several metal salts revealed that calcium, zinc and manganese ion increased the activity of the enzyme up to $117.2 \%, 111.3 \%$, and $114.4 \%$, respectively. Whereas, magnesium, ferry and ferrous ions at $5 \mathrm{mM}$ decreased the enzyme activity down to $91.9 \%, 64.8 \%$, and $71.3 \%$, respectively.

Previous studies on alkaline proteases reported that for maximum activity, some serine alkaline proteases were dependent on divalent ion such as calcium, magnesium and manganese (Kumar \& Takagi, 1998). However, Gessesse et al (2002) reported that serine alkaline protease activity produced by Nesternkonia sp was not dependent on the presence of calcium ion. The enzyme was not affected by PMSF, but, it was inhibited by another serine protease inhibitor 3,4-dichlorocoumarine at concentration of 100 (J.M,. 


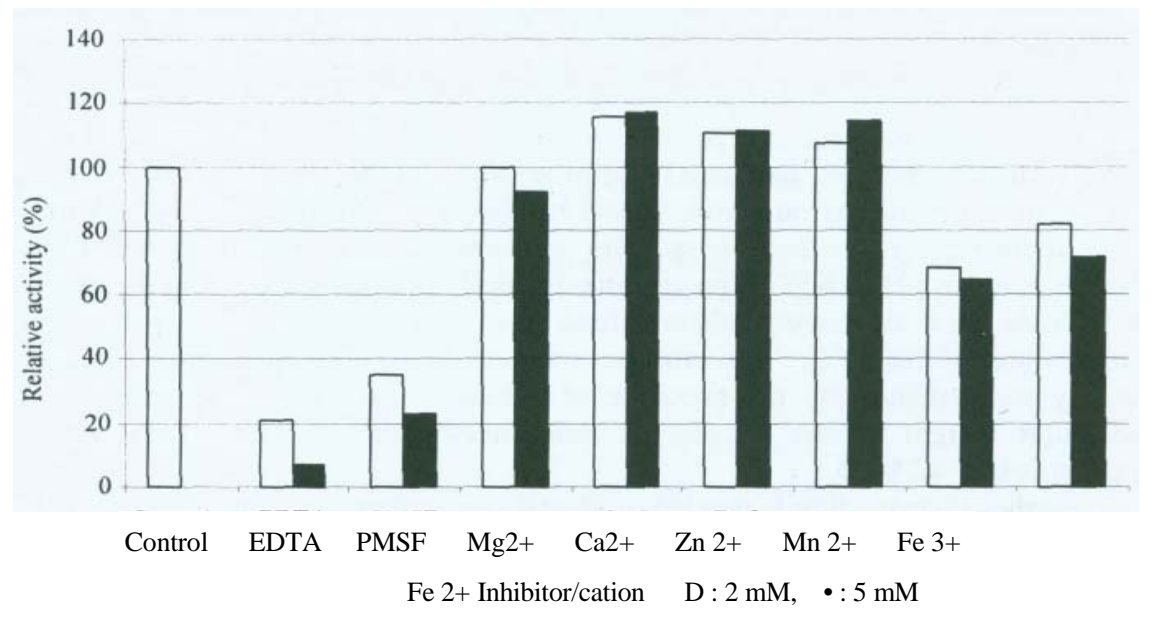

Figure 6. Et'fecl of protease inhibitor and cation on enzyme activity

\section{Molecular weight of the enzyme}

Zymogram analysis revealed that the molecular weight of the enzyme was approximately $42.8 \mathrm{kD}$ (Figure 7). That molecular weight of most Bacillus alkaline proteases reported ranges from 15 to $45 \mathrm{kD}$ (Kumar \& Takagi, 1998). A more recent report by Singh et al (2001) also stated that the molecular weight of serine alkaline protease produced by Bacillus $s p$ SSR1 was $29 \mathrm{kD}$ which was also lower than the previous reports

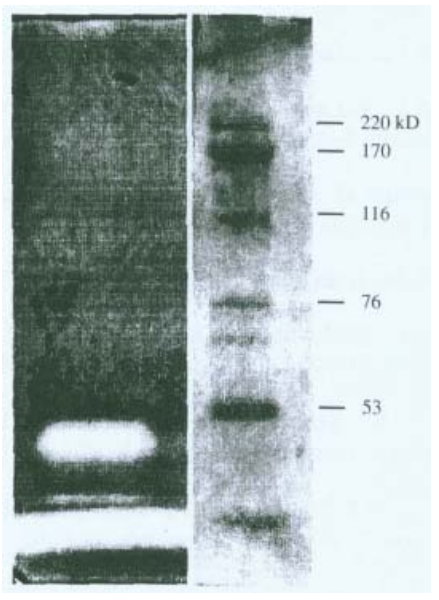

Figure 7. Zymogram otisolate D2 protease 


\section{CONCLUSION}

In this exploration of protease-producing bacteria from leather processing waste, only few bacteria that produce alkaloprotease were discovered. Among the three isolates screened. Isolate D2 produced the highest protease in submerged culture medium. Based on physical and biochemical properties of the isolate, D2 most likely belongs to Bacillus sp. The optimum activity of the enzyme produced was observed at $\mathrm{pH} 8,60^{\circ} \mathrm{C}$. The enzyme retained $70 \%$ of its activity at the range $\mathrm{pH}$ of $7-10$. At $\mathrm{pH} 8$, the enzyme also retained more than $70 \%$ of its activity at the range temperature of $52-62^{\circ} \mathrm{C}$. The enzyme was identified as serine protease and its activity was affected by the presence of calcium, zink and manganese ion. The molecular weight of the enzyme as determined using zymogram analysis was approximately $42.8 \mathrm{kD}$.

Further investigation is needed to identify the isolate using more reliable means such as 16rRNA sequencing

The enzyme can be used in a condition that is slightly alkaline at around $\mathrm{pH} 8$ and at $50-60^{\circ} \mathrm{C}$. However, to find suitable application of the enzyme, other considerations have to be taken into account such as type of substrate of the respected process. Hence, it is necessary to investigate different kinds of protein substrates such as hemoglobin, collagen, gelatin, keratin etc. Selecting the best medium to produce the enzyme is also necessary, as well as more thorough characterization of the enzyme such as the stability of the enzyme toward $\mathrm{pH}$, temperature, and some additives that might be used in enzyme application.

\section{REFERENCES}

Banerjee UC, RK Sani, W Azmi and R Soni. 1999. Thermostable alkaline protease from Bacillus brevi.t and its characterization as a laundry detergent additive, Process Biochem. 35:213-219.

Gessesse A, HK Rajni, BA Gashe arid B Mattiasson. 2002. Novel alkaline proteases from alkaliphilic bacteria grown on chicken feather. Enzyme \& Microbial Tech. 6250:1-6.

Horikoshi, K, 1971. Production of alkaline enzymes by alkalophilic microorganisms. Part 1. Alkaline protease produced by Bacillus No. 221. Agric. Biol. Chem. 36:1407-1414.

Horikoshi K, 1996. Alkaliphiles from an industrial point of view, EEMS Microbiol Riev, 18:259-270.

Johnvesly B. and GR Naik. 2001, Studies on production of thermostable alkaline protease from thermophilic Bacillus sp JB-99 in a chemically defined medium, Process Biochem. 37:139-144.

Joo HS, SG Kumar, GC Park, KT Kirn, SR Paik and CS Chang. 2002. Optimization of the production of an extracellular alkaline protease from Bacillus horikoshii, Process Biochem, 38:155-159.

Kanekar PP, SS Nilegaonkar, SS Sarnaik and As Kelkar. 2002. Optimization of protease activity of alkaliphilic bacteria isolated from an alkaline lake in India, Bioresource Tech. 85:87-93.

Kumar CG, and H Takagi 1998. Microbial alkaline proteases: From a bioindustrial viewpoint, Biochem Adv, 17:561-594. 
Isolation and selection of alkaline proteolytic bacteria - Budiasih Wahyuntari et al.

Moreira KA, TS Porto, MFS Teixeira, ALF Porto and JL Lima Filho. 2003. New alkaline protease from Nocardiopsis sp partial purification and characterization, Process Biochem.OO: 1-6 .

Singh J, N Batra, and RC Sobti 2001, Serine alkaline protease from newly isolated Bacillus sp SSR1, Process Biochem, 36:781-785.

Taylor MM, DG Bailey and SH Feaiheller. 1987. A review of the use of enzymes in tannery, J. Ame leather Chem Assoc, 82:153-165.

Walter HE. 1984. Proteinases In Methods of enzymatic analysis, (ed. H.U. Bergmeyer and M Qrassl), Verlag Chemie. Weinheim-Deerfield, Florida-Basse!, Vol. 5:271-276. 